\title{
PERCEIVED CORRUPTION IN BUSINESS ENVIRONMENT: EXPLORING THE UNDERLYING CAUSES
}

\author{
Marija Džunić, Nataša Golubović
}

\section{Introduction}

Business environment is an important determinant of national competitiveness and sustainable long-term economic growth. Business environment quality determines the risk as well as returns from investment and therefore affects investment decisions.

The business environment is largely, if not totally, beyond the control of the firms and their management. It results from existing political, legal and regulatory framework; macroeconomic policies; institutional infrastructure; social and cultural context within which transactions take place, the quality of physical and social infrastructure and many other factors. Empirical research has shown that corruption represents a serious obstacle to entrepreneurship and business (Kaufmann \& Wei, 2000; Meon \& Sekkat, 2005). Hellman et al. (2000) consider corruption, in addition to governance quality and state capture, a factor that significantly shapes business environment in transition countries.

Government has a vital role in creating and ensuring the stable and healthy socio-economic environment for businesses. By ensuring lower transaction costs on individuals and firms, wellregulated business environment allows them to operate more efficiently. According to Guriev (2004) corruption and poor institutions are key determinants of existing poor regulation and misgovernance. Breen and Gillanders (2012) consider a country's existing stock of regulation as a product of its recent history of institutional quality and corruption. Main findings of their research show that the level of corruption is the most important factor that determines the quality of the business environment, trumping the quality of institutions and a range of other indicators. Therefore, development and implementation of appropriate strategies, focused on continuous improvement of business environment are of great importance.
Although some authors justify corruption on the ground that it helps firms to deal with obstacles caused by inefficient public administration (Dreher \& Gassebner, 2013; Leff, 1964), corrupt business environment forces firms to allocate significant part of their human, financial and other resources to corrupt practices instead of focusing on innovation and development. Large companies are in better position because they have resources and capacities to protect their business interests and cope with corruption, while small and medium-sized enterprises are more strongly affected by corruption. There is also evidence that the extent of corruption varies in different regions of the same country (Linhartová \& Volejníková, 2015). This study tends to contribute to the literature on the causes of corruption. Particularly, we empirically test the relevance of various determinants of corruption in the business environment, on the example of a single transition economy. Serbia is a country where corruption is perceived as a major impediment to investing and doing business efficiently (Stošić, Nikolić, \& Đukić, 2011). In our analysis, we use data on the perceptions of corruption throughout Serbian business environment, as well as the real cases of corruption, in the form of informal payments or gifts for various purposes. We investigate to what extent corruption represents an obstacle to business transactions and offer potential explanations of the determinants of such attitudes.

The paper is organized as follows. Section 1 presents a brief overview of the main findings of the literature on corruption, its determinants and the impact on the business environment. Section 2 describes the data sources and explains the proposed methodological procedures. In sections 3 and 4 , the results of empirical tests are presented and discussed. The paper ends with a summary of the main findings. 


\section{Literature Review}

Corruption is a complex social phenomenon that has a long history. Forms, causes, mechanisms and conseqences of corruption represent a popular subject of scientific inquiries (Mauro, 1995; Paldam, 2002; Rose-Ackerman, 1999; Shleifer \& Vishny, 1993). Yet, despite numerous political, legal, economic and sociological studies, there is no globally accepted definition of corruption. Corruption is most commonly defined as the misuse or the abuse of power for personal gain and exists in both public and private sectors.

Corruption is predominantly associated with the public sector. Mauro (1995) deals only with government corruption. Shleifer and Vishny (1993) focus their attention on corruption in the public sector, where corruption is a "sale by government official of government property for personal gain" (p. 599). Perhaps the most comprehensive definition of corruption is given by Tanzi (1995), who associates corruption with the deliberate violation of impartiality in decision making process, for the purpose of appropriating benefits for oneself or for related individuals.

Regardless of its forms, it is widely believed that corruption represents a considerable impediment to sustainable growth and development (Mauro, 1995; Tanzi, 1998). High levels of corruption affect investment decisions and economic growth (Mauro, 1997). Governance and corruption issues, according to Kauffman (2005), represent key constraints to investment and business. Business environment that is conducive to growth has many dimensions, related to the quality of institutions, government policy, regulatory framework etc. (UNODC, 2013). Besides political and economic stability, a sound business environment to a great deal depends on the control of corruption. Perceptions about business environment are a fundamental factor that shapes decisions of firms. If firms perceive business environment as favourable, they will be more inclined to invest. Corruption represents a kind of tax on economic activity, which raises transaction costs (Shleifer \& Vishny, 1993). Through rising uncertainty and reduced profitability of enterprises, corruption reduces the willingness of enterprises to invest. It will in turn reduce the attractiveness of entrepreneurship; entrepreneurial talent will be diverted to less productive activities, with the negative impact on the innovation and thus economic growth (Harris \& Merwe, 2012, p. 171). There is also output loss due to the misallocation of resources (Shleifer \& Vishny, 1993), distortions of incentives, strengthening of the informal economy, changing structure of investment and government spending. Corruption negatively affects country's capacity to attract foreign direct investment, which is a major vehicle of technology transfer (Abed \& Davodi, 2002; Smarzynska \& Wei, 2000). Indices of corruption send out signals to potential investors, providing information necessary for the assessment of a country risk and the cost of doing business, and for the decision where to invest. However, some authors consider corruption as beneficial because it helps to overcome the inefficiency of the government regulations and avoid bureaucratic obstacles (Leff, 1964). According to Ali and Isse (2003), bribery is a substitute for higher wages, meaning that it saves money for the government.

In the political sphere, corruption causes the decrease of voters' confidence in elected representatives, undermines the rule of law, and undermines the reputation of government and other institutions. Corruption affects the credibility of political institutions in front of citizens and the rest of the world. According to Hodgson and Jiang (2007, p. 1057) corruption reduces levels of trust in dealing with both business and the state. It erodes confidence in public institutions, diminishes state's ability to provide public goods and services and create conducive environment for private sector development.

Furthermore, corruption affects other important determinants of business environment, such as social capital (Putnam, 1993; Fritzen, Serritzlew, \& Svendsen, 2014). Reliance on informal contacts and family, friendship, ethnic and other ties caused by corruption leads to the loss of benefits of wider cooperation and competition (Graeff \& Svendsen, 2013). It undermines the efficacy of the formal rules that are very important for the efficient market economy. Strong informal networks with bonding social ties and lack of efficient formal institutions create fertile ground for further expansion of corruption (Lipset \& Lenz, 2000; Harris, 2007). In the long run, corruption causes the increase of inequality and poverty, creating a general climate of insecurity, 
lack of trust in institutions and the general dissatisfaction of all social stratums (Rothstein \& Uslaner, 2005).

In transition countries, the collapse of the existing institutions of centrally-planned economy and slow emergence of new institutions compatible with market economy has established institutional vacuum and fertile ground for public sector corruption. Institutional weakness, such as poorly defined property rights, weak accountability of public officials and limited political competition, has had a profound impact on the susceptibility of transition countries to corruption. At the beginning of transition these countries were focused on the problem of economic transformation and privatization. Reforms of the state, public administration and of the judiciary were largely neglected (Ackerman, 1992, p. 46). These developments affected the pace of political and economic reforms and created a unique transition path for every country. Countries where transition path led to concentration of economic power in a setting of weak institutions became especially vulnerable to corruption.

The region of the Western Balkans is perceived as a region of high corruption. Corruption is perceived as a major obstacle for investment and doing business in this region (EUROCHAMBRES, 2009). This is confirmed by the results of several studies (Stošić, Nikolić, \& Đukić, 2011; Džafić et al., 2011; Budak \& Rajh, 2011). According to business representatives in Serbia, corruption is the fifth most significant obstacle to doing business, right after tax rates, inefficient government bureaucracy, political instability and access to financing (WEF, 2016). United Nations Office on Drugs and Crime study about the impact of corruption on private enterprises in Serbia reveals that corruption is a great hindrance to private enterprise and has a negative effect upon private investment (UNDOC, 2013).

The obvious negative impact of corruption on economic and social outcomes implicates that exploring possible determinants of corruption is very important. However, a serious limitation of studies that explore causes of corruption relates to the problems in its measurement. Actual corruption incidents are very hard to detect, since agents tend to hide their participation in corrupt practices. For this reason, direct measures of corruption are rarely available for research. Therefore, widely used measures of corruption are estimates based on perceptions of the frequency and level of corruption, captured by surveys. Although perceptions could possibly deviate from actual corruption incidents (Treisman, 2007), perceptions based indicators are considered a reliable indicator of corruption. In that sense, when exploring corruption determinants, empirical studies mainly rely on data about perceived corruption.

There are many possible causes of corruption suggested by the literature. Economic determinants of corruption most often include country's economic wealth (Hall \& Jones, 1999), income inequality (Paldam, 2002), economic freedom (Treisman, 2000), trade openness (Persson et al., 2003), inflation and macro-economic performance (Melgar et al., 2010). Studies related to political causes of corruption have focused on the impact of political instability (Lederman et al., 2005), political liberties (Treisman, 2000), electoral systems (Persson et al., 2003), etc.

Government is cited as the important source of corruption because extensive state regulation of the economy creates possibilities for the extraction of rents. Empirical research about origins of corruption indicates that poorly functioning institutions and policies undermine free trade and competition, thus leading to corruption. Based on the analysis of institutional quality in 18 OECD countries Dreher et al. (2009) find that increase in institutional quality reduces the level of corruption. Extensive regulation of market entry, in the form of procedures, costs and time to start a new business, is consistent with higher levels of corruption (Djankov et al., 2002). A highly diversified trade tariff may encourage public officials to extract bribes from importers (Gatti, 1999).

There are two basic sources of corruption related to government activity. The first concerns the way government performs its activities, such as tax collection, customs and licensing. Powers of the government officials are often accompanied by discretion, nontransparent or ambiguous procedures, creating favourable conditions for extracting bribes. Therefore, the rule of law and the quality of bureaucracy are important determinants of corruption (Rauch \& Evans, 1997; Ali \& Isse, 2003; Brunetti \& Weder, 2004). Corruption tends to be lower in the environment characterized by strong and effective judicial system, contract 
enforceability and professional bureaucracy. The second includes political actors involved in political decision making, such as legislation, privatization and contracting, whose activities may cause a substantial dysfunction of the legislative, executive and judicial branches of power. Activities of interest groups, which are often illegal and non-transparent, may influence government policies, regulations and laws, with the purpose of achieving private benefits.

Institutional and generalized trusts are also perceived as relevant predictors of corruption (Rothstein \& Uslaner, 2005). Corrupt environments are characterized by considerable deterioration of trust in institutions and politicians, as well as in business partners.

\section{Data and Methodology}

For the purpose of this study, data from the fifth round of Business Environment and Enterprise Performance Survey - BEEPS V (EBRD, 2015) were used. The BEEPS survey has been conducted as a joint initiative of the European Bank for Reconstruction and Development and the World Bank, since 1999, as a firm-level survey based on interviews with firm managers, with the aim of assessing the quality of the business environment and main challenges of the private sector development. The fifth round of the survey, implemented over the period 2012-2014, covered 15,883 enterprises in 30 countries of Eastern Europe and Central Asia. The research in this paper is based on data from the survey implemented in Serbia. Regarding sampling implementation, in each country two sampling frames have been used: the first, an official frame of establishments supplied by the official sources in the country (Business Registers Agency in the case of Serbia); and the second, consisting of enterprises interviewed in previous round of the survey. In particular, out of the total number of contacted establishments in Serbia (836), the number of non-eligible units was 73,40 establishments were impossible to contact, while 363 refused to participate in the survey. The number of completed interviews was 360 , indicating the response rate of 0.43 . The interviews with senior managers were conducted from January to August 2013. The data used in this paper express their attitudes about relations between business and government. The ownership structure of the surveyed enterprises is as follows: 317 enterprises are $100 \%$ owned by domestic private capital, 25 enterprises are of $100 \%$ private foreign ownership, 10 enterprises have a certain percentage of state capital (from 1 to $93 \%$ ), while the rest (8 enterprises) report combined ownership. All types of enterprises (micro, small, medium and large) are encompassed by the survey.

In the attempt to explore the underlying causes of corruption perceptions, we test whether the perceptions of corruption as an obstacle to business transactions differ based on distinctive features of the firms. Besides cross-tabulations and descriptive statistics, a nonparametric test for the analysis of variance was performed, as to determine whether there are statistically significant differences in the perceived spread of corruption across a number of independent variables (regions, size of locality, industry, size, and years of operation). Since the examined variables consist of more categories, with a clear ordering and equally spaced intervals between the values, the method of choice is the Kruskal-Wallis one-way analysisof-variance test, H (Kruskal \& Wallis, 1952; 1953). This is a non-parametric version of the one-way ANOVA and an extension of the MannWhitney $U$ test, used when the assumption of normality is violated, as in the case of data used for this study. The data in our sample meet all the assumptions that underpin the application of Kruskal-Wallis $\mathrm{H}$ test. All the dependent variables are measured on a Likert scale with 5 or more points; independent variables consist of two or more categorical independent groups; observations are independent; and, most importantly, distributions of scores (for each group of independent variable) have the same shape (variability).

Additionally, by specifying an ordered logistic regression model, we explore the determinants of the attitudes on corruption. We estimate the relations between the perceptions of corruption and several independent variables (frequencies of unofficial payments and gifts for different purposes, perceived impact of informal payments on government decisions, perceptions of the importance of political stability and courts for business operations). As the dependent variable in the model is categorical and ordered (perceptions of corruption as an obstacle for doing business, expressed by 5-point Likert scale), we estimate an ordered logistic regression model, also known as proportional odds model 
(Aitchison \& Silvey, 1957; McKelvey \& Zavoina, 1975; Long \& Freese, 2014).

Using the ologit model, we obtain the probabilities of observing each of the possible outcomes $i$ of dependant variable (degrees of perceived corruption) within the range of the estimated cut-points. In other words, the probability of outcome $i$ is calculated as the probability that the value of the linear function of the independent variables (including the error term $u_{j}$ ) is within the range of estimated cut-points $\left(k_{i}\right)$ :

$$
\begin{aligned}
& \operatorname{Pr}\left(y_{j}=i\right)=\operatorname{Pr}\left(k_{i}-1<\beta_{1} x_{1 j}+\right. \\
& \left.+\beta_{2} x_{2 j}+\cdots+\beta_{k} x_{k j}+u_{j} \leq k_{i}\right)
\end{aligned}
$$

In this model, the relationship between each pair of outcome groups is the same and it is described by one set of coefficients, so only one equation is estimated. Two procedures are performed for testing the proportional odds assumption: a likelihood ratio test (Wolfe \& Gould, 1998) and Brant test (Brant, 1990).

Based on the model, we obtain predictions regarding the effects that improving business environment can have on corruption perceptions of the existing and potential business actors.

\section{Results}

\subsection{Data Overview and Descriptive Statistics}

Throughout transition countries, firm managers report that top three obstacles, as perceived by each firm, are competitors' practices in the informal sector, access to finance and electricity issues (EBRD, 2015a). However, corruption still remains one of the biggest obstacles, even though the survey results indicate there has been a significant decline in the share of firms reporting that informal payment or gifts were expected or requested from them in different interactions with government officials. One of the reasons for this decline, as reported, might be the introduction of electronic filing and payment systems, which reduce the possibilities for officials to request informal payments. Still, there are a number of firms that report significant share of their annual sales for the purpose of "getting things done".

The top three business environment obstacles identified by firms in Serbia are political instability, tax rates and access to finance
(EBRD, 2015). These results are determined by the intensive political developments in the period prior to survey - presidential and parliamentary elections, followed by the change of the ruling party. The new government has introduced a fiscal consolidation reform, which caused a rise in the tax rates. Access to finance has become the biggest problem for Serbian firms, due to the lack of credit funds and increased interest rates. Besides, corruption appears to be an important obstacle in Serbia. As for $6.11 \%$ of the total number of surveyed firms corruption represents the biggest obstacle for business operations.

The scope for corruption appears every time a firm interacts with government officials or service providers. However, the perceptions of firms about corruption activities tend to differ, depending on their size, industry, region or ownership structure. Small firms in Serbia complain the most about corruption, while all the complaints arise from the firms that are $100 \%$ owned by domestic private capital. The majority of firms that complain about corruption are operating in Belgrade, the capital of Serbia.

A detailed statistics on firms' perceptions of corruption as an obstacle of their current business operations is presented in Tab. 1 (the responses are assigned scores from $0=N o$ obstacle to $4=$ Very severe obstacle). The data indicate that corruption is widespread in the business environment. Less than a half of the surveyed firms do not experience any problems with corruption, while $6.11 \%$ perceive corruption as a very severe obstacle to their business. Furthermore, over $40 \%$ of the respondents claim that total annual cost of their operations would decrease if corruption was no longer an obstacle (not enclosed in the table). The mean value of expected cost decrease reported by the firms is $11.75 \%$.

In order to explore whether such attitudes on corruption stem from real cases of corrupt activities or merely perceptions on the spread of corruption in their environment, the respondents have been asked to report if any gifts or informal payments had been expected or requested from them when meeting tax officials, obtaining an import license or obtaining an operating license. The survey data indicate that $5-6 \%$ of any interactions with the government authorities are followed by requesting or expected gifts of informal payments from the firms. Additionally, 3 out of 29 firms that have attempted to secure 
Tab. 1: To what degree is corruption an obstacle in business environment

\begin{tabular}{l|c} 
No obstacle & $42.50 \%$ \\
\hline Minor obstacle & $21.39 \%$ \\
\hline Moderate obstacle & $15.28 \%$ \\
\hline Major obstacle & $11.11 \%$ \\
\hline Very severe obstacle & $6.11 \%$ \\
\hline Don't know / No answer & $3.61 \%$ \\
\hline Total & $\mathbf{1 0 0 \%}$ \\
\hline
\end{tabular}

Source: BEEPS V (EBRD, 2015)

Tab. 2: The frequency of informal payments

\begin{tabular}{l|c|c|c|c} 
& $\begin{array}{c}\text { It is common to pay } \\
\text { additional payments } \\
\text { "to get things done" }\end{array}$ & $\begin{array}{c}\text { To deal with } \\
\text { customs/imports }\end{array}$ & $\begin{array}{c}\text { To deal with } \\
\text { courts }\end{array}$ & $\begin{array}{c}\text { To deal with taxes } \\
\text { and tax collection }\end{array}$ \\
\hline Never & $25.28 \%$ & $41.39 \%$ & $42.50 \%$ & $39.72 \%$ \\
\hline Seldom & $21.94 \%$ & $15.83 \%$ & $14.17 \%$ & $17.22 \%$ \\
\hline Sometimes & $24.17 \%$ & $14.17 \%$ & $14.17 \%$ & $14.72 \%$ \\
\hline Frequently & $\mathbf{8 . 3 3 \%}$ & $\mathbf{4 . 1 7 \%}$ & $\mathbf{5 . 5 6 \%}$ & $\mathbf{3 . 6 1 \%}$ \\
\hline Very frequently & $\mathbf{2 . 5 0 \%}$ & $\mathbf{1 . 1 1 \%}$ & $\mathbf{0 . 8 3} \%$ & $\mathbf{1 . 1 1 \%}$ \\
\hline Always & $\mathbf{0 . 8 3 \%}$ & $\mathbf{0 . 5 6 \%}$ & $\mathbf{0 . 5 6 \%}$ & $\mathbf{0 . 0 0 \%}$ \\
\hline Don't know & $16.94 \%$ & $22.78 \%$ & $22.22 \%$ & $23.61 \%$ \\
\hline Total & $\mathbf{1 0 0 \%}$ & $\mathbf{1 0 0 \%}$ & $\mathbf{1 0 0 \%}$ & $\mathbf{1 0 0 \%}$ \\
\hline
\end{tabular}

Source: BEEPS V (EBRD, 2015)

a government contract declared that a certain percentage $(2-8 \%)$ of the contract value "would typically be paid in informal payments or gifts to secure the contract". Firms report that they pay certain percentages of total annual sales as informal payments or gifts to public officials to "get things done" with regard to customs, taxes, licenses, regulations, services etc. About $8 \%$ of the surveyed firms report that in their business environment, an establishment such as theirs pays a certain percentage of total annual sales in informal payments or gifts to public officials.

The perceptions of the respondents on how common it is for firms in their line of business to have to pay some irregular "additional payments or gifts" to get things done with regard to customs, taxes, licenses, regulations, services etc. are presented in Tab. 2 (the responses are assigned scores from $1=$ Never to $6=$ Always). Only a quarter of respondents believe that it is never common for firms to pay additional payments or gifts for such purposes, while for $12 \%$ of the surveyed firms, it is quite common to make such payments. Beside perceptions on how common it is for firms to pay additional payments and gifts, the respondents have reported on the frequency of payments for different purposes (to deal with customs, courts and taxes).

It is assumed that the main reason for firms' making unofficial payments or gifts is for them to gain advantages in the drafting of laws, decrees, regulations, and other binding government decisions. The following table presents the extent to what private payments/ gifts or other benefits to parliamentarians and government, regional or local officials to affect their votes or the content of government decrees, had a direct impact on business of the surveyed firms (Tab. 3). 


\section{Ekonomie}

Tab. 3:

The impact of unofficial payments

\begin{tabular}{l|r|r|r|r|r|r} 
& No impact & \multicolumn{1}{c|}{ Minor } & Moderate & Major & Decisive & N/A \\
\hline $\begin{array}{l}\text { To affect parliamentary } \\
\text { votes }\end{array}$ & $59.17 \%$ & $7.50 \%$ & $3.61 \%$ & $1.39 \%$ & $0.83 \%$ & $27.50 \%$ \\
\hline $\begin{array}{l}\text { To affect government } \\
\text { decrees }\end{array}$ & $59.72 \%$ & $6.39 \%$ & $3.61 \%$ & $1.67 \%$ & $0.83 \%$ & $27.78 \%$ \\
\hline $\begin{array}{l}\text { To affect local and } \\
\text { regional officials }\end{array}$ & $55.83 \%$ & $9.17 \%$ & $4.72 \%$ & $1.67 \%$ & $1.11 \%$ & $27.50 \%$ \\
\hline
\end{tabular}

Source: BEEPS V (EBRD, 2015)

\section{Tab. 4: Descriptive statistics}

\begin{tabular}{l|c|c|c|c|c}
\multicolumn{1}{c|}{ Variable } & Obs. & Mean & St. dev. & Min & Max \\
\hline Corruption as obstacle to business & 202 & 1.148515 & 1.307355 & 0 & 4 \\
\hline Frequency of payments - customs & 202 & 1.792079 & 1.068004 & 1 & 6 \\
\hline Frequency of payments - courts & 202 & 1.861386 & 1.115514 & 1 & 6 \\
\hline Frequency of payments - taxes & 202 & 1.831683 & 1.022817 & 1 & 5 \\
\hline Impact of payments - parliamentarians & 202 & 1.301980 & 0.714384 & 1 & 5 \\
\hline Impact of payments - government & 202 & 1.297030 & 0.740372 & 1 & 5 \\
\hline Impact of payments - local/reg. officials & 202 & 1.396040 & 0.829544 & 1 & 5 \\
\hline Courts as obstacle to business & 202 & 0.861386 & 1.226001 & 0 & 4 \\
\hline Political instability as obstacle & 202 & 1.752475 & 1.333875 & 0 & 4 \\
\hline
\end{tabular}

Source: BEEPS V (EBRD, 2015)

\section{Tab. 5: Kruskal-Wallis test}

\begin{tabular}{l|l|c|c|c}
\multicolumn{1}{c|}{ Dependent variable } & \multicolumn{1}{c|}{$\begin{array}{c}\text { Independent } \\
\text { variable }\end{array}$} & df & X2 (with ties) & p-value \\
\hline \multirow{2}{*}{ Corruption as obstacle } & Industry & 2 & 6.882 & $\mathbf{0 . 0 3 2 0}$ \\
\cline { 2 - 5 } & Region & 3 & 9.973 & $\mathbf{0 . 0 1 8 8}$ \\
\hline Unofficial payments - Customs & Size of locality & 3 & 8.838 & $\mathbf{0 . 0 3 1 5}$ \\
\hline Unofficial payments - Courts & Region & 3 & 9.729 & $\mathbf{0 . 0 2 1 0}$ \\
\hline Impact of payments - parliamentarians & Industry & 2 & 8.105 & $\mathbf{0 . 0 1 7 4}$ \\
\hline Impact of payments - government decrees & Industry & 2 & 13.052 & $\mathbf{0 . 0 0 1 5}$ \\
\hline
\end{tabular}

Source: author's calculations based on BEEPS V (EBRD, 2015)

Descriptive statistics of the variables used in the analysis that follows is presented in Tab. 4. Observations with missing values (Don't know, Does not apply) have been omitted prior to the calculations.

\subsection{Kruskal-Wallis Equality-of- Populations Rank Test}

The next step of the analysis is to test whether the perceptions of corruption as an obstacle in the business environment in Serbia differ based 
on distinctive features of the firms (firm size, region, industry or the size of locality where firms operate, number of years of operation). The data in our sample meet the assumptions that underpin the use of Kruskal-Wallis $\mathrm{H}$ test. The results of the Kruskal-Wallis $\mathrm{H}$ are presented in Tab. 5 (only results at $p<0.05$ significance level are displayed).

The Kruskal-Wallis $\mathrm{H}$ test showed that there was a statistically significant difference in perceiving corruption as an obstacle to business operations between the manufacturing, retail and other services, as well as between the four regions of Serbia. Also, frequency of unofficial payments/gifts that firms would make in a given year to deal with customs differ significantly between localities of different sizes, while frequency of unofficial gifts paid to deal with courts are significantly different between Serbian regions. The results also indicate that there is a statistically significant difference between firms from different industries regarding the extent to which private payments to parliamentarians (paid to affect their votes) have a direct impact on their business. Belonging to manufacturing, retail or other services industry is also a valid predictor of the extent that private payments to government officials (paid to affect the content of government decrees) have a direct impact on firms' business.
The results of the performed test prove that, depending on the industry they belong to, region they operate in, or size of their city/town, firms have different perceptions of how corruption, in the form of unofficial payments or gifts to public officials, affects their business operations. The following analysis is aimed at exploring the causes that determine such perceptions.

\subsection{Estimation of the Perceived Corruption Determinants}

The survey data on corruption in Serbian business environment indicate a significant prevalence of corruption, as perceived by economic actors. In the attempt to explore the underlying causes of corruption perceptions, we test whether the attitudes on corruption are determined by real cases of corruption or perceptions of the impact that informal payments may have on the business operations. Specifying the ordered logistic regression model, we test the explanatory power of several potential determinants of attitudes on corruption. The response variable in the model is defined as the degree to which corruption presents an obstacle to business operations of respondents, measured by 5 point Likert scale. The explanatory variables used in the model include: the frequencies of unofficial payments or gifts for different purposes (dealing with customs, courts or

\section{Tab. 6: Regression results for determinants of perceived corruption}

\begin{tabular}{|c|c|c|c|c|c|c|}
\hline \multicolumn{4}{|l|}{ Ordered logistic regression } & \multicolumn{3}{|c|}{$\begin{array}{l}\text { Number of obs }=202 \\
\text { LR chi2 }(5)=50.63 \\
\text { Prob }>\text { chi2 }=0.0000 \\
\text { Pseudo } R 2=0.0893\end{array}$} \\
\hline Corruption as obstacle & Coef. & Std. Err. & Z & $\mathrm{P}>|\mathrm{z}|$ & \multicolumn{2}{|c|}{ [95\% Conf. Interval] } \\
\hline Unofficial payments-customs & .3581645 & .1489654 & 2.40 & 0.016 & .0661977 & .6501313 \\
\hline Unofficial payments-taxes & .4267126 & .1554440 & 2.75 & 0.006 & .1220479 & .7313772 \\
\hline Impact-local/regional officials & .3267984 & 1629264 & 2.01 & 0.045 & .0074685 & .6461284 \\
\hline Courts as obstacle & .2146813 & .1148418 & 1.87 & 0.062 & -.0104044 & .439767 \\
\hline Political instability as obstacle & .1670583 & .1030101 & 1.62 & 0.105 & -.0348378 & .3689545 \\
\hline /cut1 & 2.113232 & .3855439 & & \multicolumn{3}{|c|}{ (Ancillary parameters) } \\
\hline /cut2 & 3.030764 & .4147334 & & & & \\
\hline /cut3 & 4.192927 & .4714150 & & & & \\
\hline /cut4 & 5.335898 & .5401861 & & & & \\
\hline
\end{tabular}


taxes), the impact that unofficial payments to public officials (parliamentarians, government officials, local and regional officials) have on the business operations of the respondents, as well as attitudes of the respondents related to the quality of the judicial system and political stability.

The empirical estimates of the ologit model are presented in Tab. 6.

The model summary indicates the specifics of the fitted model. The LR Chi-Square of 50.63 with a $p$-value of 0.0000 implies that the model as a whole is statistically significant, as compared to the null model with no predictors. It confirms that least one of the predictors' regression coefficient is not equal to zero. Degrees of freedom of the Chi-Square distribution used to test the LR Chi-Square statistic are defined by the number of predictors in the model. The value of pseudo-R-squared is subject to a variety of interpretations; however it does not indicate the proportion of variance for the response variable explained by the predictors, as the R-square found in OLS regression. Ancillary parameters (cut points) shown in the regression output are used to differentiate adjacent levels of the dependant variable, indicating the cuts in the continuous latent variable. Since our response variable has 5 levels, the number of cut points (thresholds) is 4 . For example, cut1 differentiates the lowest level of the response variable (corruption is no obstacle to business operations) from all the higher levels of this variable, given that values of all predictors is zero. In our case, all values of latent variable under 2.11 would imply that corruption is no obstacle to business, given that firms never make informal payments or gifts to deal with customs or taxes; that these kinds of payments have no impact on firms' operations, and that courts and political instability are not perceived as obstacles to business.

In our model, business actors that are frequently exposed to the undertakings of paying unofficial payments or gifts in order to deal with customs and taxes tend to apprehend corruption as a severe obstacle to their business operations. According to the values of the ordered log-odds regression coefficients, for a one unit increase in these two predictors the perceptions of corruption are expected to change in the ordered logodds scale by 0.36 and 0.43 respectively, other variables held constant. For example, a one unit increase in frequency of informal payments aimed at "getting things done" in dealing with the customs would result in 0.36 unit increase in the ordered log-odds for response variable to be in a higher category (higher degree to what corruption is perceived as an obstacle to business operations), while other variables in the model are held constant.

Similar to this, respondents whose operations have been subject to decisive impact of unofficial payments, gifts or other benefits to local or regional government officials, tend to perceive corruption as harmful to their business. The ordered log-odds estimate for a one unit increase in this predictor on the expected level of the dependent variable is 0.33 , given the other variables are held constant in the model. On the other hand, perceptions of respondents related to the judicial efficiency or political stability as determinants of business operations do not have statistical significance (alpha level set at 0.05 ) in explaining corruption perceptions.

\section{Discussion and Interpretation of Research Results}

It is clear from our results that firms have different perceptions of how corruption, in the form of unofficial payments or gifts to public officials, affects their business operations, depending on the industry they belong to, region they operate in, or size of their locality (see part 3.3). The empirical analysis indicates that there are significant differences in perceiving corruption as an obstacle to business operations between the manufacturing, retail and other services, as well as between the regions of the analysed country. Perceptions on frequency of unofficial payments that firms make to deal with customs differ significantly between firms from localities of different sizes, while perceptions on frequency of unofficial payments to deal with courts are significantly different between regions. These findings are in line with the results of recent empirical analysis of the business consequences of local bribery environments (Hanoushek \& Kochanova, 2016), indicating that bureaucratic corruption is a local phenomenon, that depends not only on country, but also industry, firm and market size. Furthermore, such findings imply the importance of identifying the potential determinants of attitudes on corruption.

The results of the ordered logistic regression models are most commonly interpreted in 


\section{Tab. 7: Approximate likelihood-ratio test of proportionality of odds}

chi2(15)

15.5400

Prob $>$ chi2

0.4133

Source: author's calculations based on BEEPS V (EBRD, 2015)

\section{Tab. 8: Brant test of parallel regression assumption}

\begin{tabular}{l|c|c|c}
\multicolumn{1}{c|}{ Variable } & Chi2 & p>chi2 & df \\
\hline All & 18.52 & $\mathbf{0 . 2 3 6}$ & 15 \\
\hline Unofficial payments-customs & 0.32 & 0.956 & 3 \\
\hline Unofficial payments-taxes & 1.38 & 0.711 & 3 \\
\hline Impact-local/regional officials & 5.41 & 0.144 & 3 \\
\hline Courts as obstacle & 2.99 & 0.393 & 3 \\
\hline Political instability as obstacle & 4.99 & 0.173 & 3 \\
\hline
\end{tabular}

Source: author's calculations based on BEEPS V (EBRD, 2015)

terms of proportional odds ratios. As ordered logit models estimate a single equation over all levels of dependent variable, a test of the proportional odds assumption is required to confirm the validity of one equation model. This would mean that the relationship between each pair of outcome groups is the same and described by one set of coefficients. Testing the proportional odds assumption is performed using two procedures: a likelihood ratio test
(Wolfe \& Gould, 1998) and Brant test (Brant, 1990). Results are displayed in Tabs. 7 and 8.

Both test yield non-significant results, indicating that the assumption of parallel-lines model is not violated and that the relations between each pair of outcome groups in our model are the same. After obtaining proportional odds ratios, the model yields the following results (Tab. 9).

\section{Tab. 9: Proportional odds ratios}

\begin{tabular}{|c|c|c|c|c|c|c|}
\hline \multicolumn{4}{|l|}{ Ordered logistic regression } & \multirow{2}{*}{\multicolumn{3}{|c|}{$\begin{array}{l}\text { Number of obs }=202 \\
\text { LR chi2(5) }=50.63 \\
\text { Prob }>\text { chi2 }=0.0000 \\
\text { Pseudo } R 2=0.0893\end{array}$}} \\
\hline \multicolumn{4}{|l|}{ Log likelihood = -258.2548 } & & & \\
\hline Corruption as obstacle & Odds ratio & Std. Err. & Z & $\mathrm{P}>|\mathrm{z}|$ & \multicolumn{2}{|c|}{ [95\% Conf. Interval] } \\
\hline Unofficial payments-customs & 1.430701 & .2131249 & 2.40 & 0.016 & 1.068438 & 1.915792 \\
\hline Unofficial payments-taxes & 1.532212 & .2381732 & 2.75 & 0.006 & 1.129808 & 2.077940 \\
\hline Impact-local/regional officials & 1.386522 & .2259011 & 2.01 & 0.045 & 1.007496 & 1.908139 \\
\hline Courts as obstacle & 1.239467 & .1423425 & 1.87 & 0.062 & 0.989650 & 1.552345 \\
\hline Political instability as obstacle & 1.181823 & .1217398 & 1.62 & 0.105 & 0.965762 & 1.446222 \\
\hline /cut1 & 2.113232 & .3855439 & & \multicolumn{3}{|c|}{ (Ancillary parameters) } \\
\hline /cut2 & 3.030764 & .4147334 & & & & \\
\hline /cut3 & 4.192927 & .4714150 & & & & \\
\hline /cut4 & 5.335898 & .5401861 & & & & \\
\hline
\end{tabular}


We interpret the proportional odds ratios in the following manner: for a one unit increase in frequency of informal payments to deal with customs (other variables in the model held constant), the odds for corruption to be perceived as very severe obstacle (level 4 ) versus the combined lower degrees of corruption as an obstacle are 1.43 times greater. Likewise, since the ordered logit model estimates one equation over all levels of the dependent variable, these odds hold for the combined higher levels of dependent variable (levels 4 and 3 ), versus combined lower levels (2, 1 and 0$)$, and so on. For a one unit increase in the second predictor (frequency of informal payments to deal with taxes), the odds of dependent variable to take highest value are 1.53 greater than the combined lower values. Similarly, a one unit increase in perceived impact of informal payments to local and regional officials on firms increases the odds for perceiving corruption as an obstacle 1.38 times.

In the output above, the following predictors are found to be statistically significant in estimating the perceptions of corruption: the frequencies of unofficial payments or gifts for dealing with customs ( $p=0.016)$, the frequencies of unofficial payments or gifts for dealing with taxes $(p=0.006)$ and the impact of unofficial payments to local or regional government officials aimed at affecting their votes or content of government decrees $(p=0.045)$.

Such findings are rather expected, taking into account the local context and the results of a number of previous studies of corruption and doing business in Serbia. Although there is a common view of the prevalence of corruption in the areas that require frequent interactions with public officials (customs clearings or tax inspections) throughout the Western Balkans region, the prevalence of business bribery in Serbia is significantly higher than the average for the Western Balkans (UNODC, 2013). According to the same study, customs officers, municipal and provincial officers tend to be the type of public officials that are more often involved in bribery. Prior investigations of corruption at the customs in Serbia (Begović et al., 2002) indicate that corruption is a quite common occurrence regarding the customs and that business people have little faith in the possibility of effective protection from the corruption at the customs. Complex tax systems combined with excessive discression of tax officials and frequent contacts between tax officials and firms are identified as the main causes of the spread of corruption in this public service (Tanzi, 2013). The organized commitment of tax fraud by persons in government positions and with decision-making power has been reported as the most important offence category processed by Serbian courts in the last two decades (Van Duyne et al., 2012). Local government is perceived as an important actor in enhancing the quality of business environment (Janković-Milić et al., 2014). A more recent study on corruption in Serbian economy (CLDS, 2014) supports the notion that the level of corruption in Serbian business environment is still rather substantial. Frequent encountering corruption among the public officials at the level of the local government, as well as at the public services most frequently contacted by the business representatives seem to be significant determinants of their apprehension of corruption as an obstacle in the business environment, as expected in our model.

Baseline results of our study fit in line with a number of previous empirical investigations that accentuate the inefficiencies on administrative and political levels as significant predictors of corruption in business environment. Weak institutions and inefficient regulations have been identified as factors that fuel corruption (Dreher \& Gassebner, 2013). Based on the analysis of CEE and CIS countries, De Rosa et al. (2015) indicate that bribery is more harmful in countries where corruption is more prevalent and the institutions are weak. Similarly, an investigation of corruption in business environment in transition countries (Nowak, 2001) confirms that inefficiency at administrative levels determines the extent to which corruption can find fertile ground to spread. According to a recent study of corruption from a business sector perspective in western Balkans (Budak \& Rajh, 2011), business representatives who perceive a rise in corruption in their environment tend to attribute this problem exclusively to the government. Corruption is found to have a deteriorating effect on business climate, altering the firms' incentives to grow, invest or innovate, which leads to low-quality business environment (Blackburn \& Forgues-Puccio, 2009; Gauthier \& Goyette, 2014; O'Toole \& Tarp, 2014). 
In a survey of firms worldwide, Brunetti et al. (1997) accentuate that corruption is among the highest obstacles for doing business, especially in the case of underdeveloped countries. Focusing on nine CEE countries, Gamberoni et al. (2016) investigate how corruption in business environment affects the total factor productivity. They find evidence that in small countries, with weak quality and effectiveness of its regulations, increase in corruption is associated with rising misallocation of capital and labour across firms. Consequently, our findings do not provide empirical support for the argument that corruption can benefit economic performance in the environment of inefficient institutional environments, often referred to as "the speed money hypothesis" (Leff, 1964; Bardhan, 1997).

Based on the model developed in this paper, useful predictions can be obtained regarding the effects that anti-corruption policy measures, related to strengthening the institutional framework, increasing transparency and suppressing bribes, can have on corruption perceptions of the existing and potential business actors. For example, we can predict with the significance level of $p=0.000$, that the probability of business actors perceiving corruption as a very severe obstacle in the environment of frequent bribes and unofficial payments and decisive impact of such payments to local and regional officials on firms (i.e. all predictors holding highest values) is 0.82 . On the other hand, the probability that business actors will not see corruption as obstacle to their business in an environment with no bribes and informal gifts is as high as 0.73 . Predicted probabilities of each of the values of our dependent variable (no obstacle - very severe obstacle) with the highest and lowest values of predictor variables are presented in Tab. 10).

\section{Tab. 10: Adjusted predictions of perceived corruption levels}

\begin{tabular}{|c|c|c|c|c|c|c|c|}
\hline \multicolumn{2}{|c|}{$\begin{array}{l}\text { Predictions of Corruption } \\
\text { as obstacle to business }\end{array}$} & \multirow{2}{*}{$\begin{array}{c}\text { Margin } \\
.7313645\end{array}$} & \multirow{2}{*}{$\begin{array}{c}\begin{array}{c}\text { Delta } \\
\text { method }\end{array} \\
\text { Std. Err. } \\
.0528766\end{array}$} & \multirow{2}{*}{$\begin{array}{c}\mathbf{z} \\
13.83\end{array}$} & \multirow{2}{*}{$\begin{array}{l}P>|z| \\
0.000\end{array}$} & \multicolumn{2}{|c|}{ [95\% Conf. Interval } \\
\hline \multirow{5}{*}{$\begin{array}{l}\text { All predictors } \\
\text { held at lowest } \\
\text { levels }\end{array}$} & No obstacle & & & & & .6277282 & .8350008 \\
\hline & Minor obstacle & .1406722 & .0288015 & 4.88 & 0.000 & .0842223 & .1971221 \\
\hline & Moderate obstacle & .0840760 & .0216458 & 3.88 & 0.000 & .0416510 & .1265010 \\
\hline & Major obstacle & .0294617 & .0101565 & 2.90 & 0.004 & .0095554 & .0493680 \\
\hline & Very severe obstacle & .0144256 & .0059902 & 2.41 & 0.016 & .0026851 & .0261661 \\
\hline \multirow{5}{*}{$\begin{array}{l}\text { All predictors } \\
\text { held at } \\
\text { highest levels }\end{array}$} & No obstacle & .0085146 & .0063711 & 1.34 & 0.181 & -.003972 & .0210017 \\
\hline & Minor obstacle & .0125290 & .0088394 & 1.42 & 0.156 & -.004795 & .0298540 \\
\hline & Moderate obstacle & .0432569 & .0276391 & 1.57 & 0.118 & -.010914 & .0974284 \\
\hline & Major obstacle & .1129983 & .0637427 & 1.77 & 0.076 & -.011935 & .2379318 \\
\hline & Very severe obstacle & .8227012 & 1015568 & 8.10 & 0.000 & .6236535 & 1.021749 \\
\hline
\end{tabular}

Source: author's calculations based on BEEPS V (EBRD, 2015)

It is clear from the output above that the probability that business actors will perceive corruption being an obstacle to business significantly decreases in the environment cleared from the practices of informal payments in business transactions.

\section{Conclusions}

Corruption is identified as a serious obstacle to business transactions and an impediment to economic growth and investment. The existing literature indicates that corruption tends to be lower in the environment characterized by strong and effective institutions, contract enforceability and professional bureaucracy. In this study we examine the perceptions of corruption in the business community and attempt to offer possible explanations of the underlying causes of attitudes towards corruption.

Our research provides evidence on the relevance of institutional environment for doing business. The main findings of this 
study indicate that the frequency of unofficial payments or gifts that business actors need to make in order to deal with public services (customs, tax office) act as significant predictors of corruption perceptions regarding business environment. Similarly, perceptions of corruption as harmful for business operations tend to increase in the ambience where firms are exposed to discretionary power of public officials at the local and regional level, subject to unofficial payments or gifts.

The findings imply the relevance of considering perceptions of corruption in the business community in view of designing effective anti-corruption policies and strategies. The specified model allows the possibility of predicting the probable effects that anticorruption policy measures, related to the improvement of business environment in terms of strengthening integrity and transparency of public services, can have on corruption perceptions of the existing and potential business actors. Important implication of the research is that targeted action of national governments against corruption can increase the efficiency of doing business, particularly in countries with weak institutions and low trust in authorities. Although reducing the level of corruption and improving the image of a country is not an easy task, willingness and readiness of government to put in place legislations and regulations to control actual corruption is an important sign to business actors.

The authors are grateful to the Republic of Serbia Ministry of Education, Science and Technological Development for the funds and support that made this research possible.

\section{References}

Abed, G. T., \& Davoodi, H. R. (2000). Corruption, Structural Reforms and Economic Performance in the Transition Economies [IMF Working Paper 00/132]. Washington, DC: IMF. https://doi.org/10.5089/9781451855371.001.

Ackerman, B. (1992). The Future of Liberal Revolution. New Haven: Yale University Press.

Aitchison, J., \& Silvey, S. D. (1957). The Generalization of Probit Analysis to the Case of Multiple Responses. Biometrika, 44(1/2), 131140. https://doi.org/10.2307/2333245.

Ali, A., \& Isse, H. (2003). Determinants of Economic Corruption: A Cross-Country Comparison. Cato Journal, 22(3), 459-466.
Bardhan, P. (1997). Corruption and Development: a review of issues. Journal of Economic Literature, 35(3), 1320-1346.

Begović, B., Mijatović, B., Sepi, R., Vasović, M., \& Vuković, S. (2002). Corruption at the Customs: combating corruption at the customs administration. Belgrade: Center for LiberalDemocratic Studies.

Blackburn, K., \& Forgues-Puccio, G. F. (2009). Why is Corruption Less Harmful in Some Countries than in others? Journal of Economic Behavior and Organization, 72(3), 797-810. https://doi.org/10.1016/j.jebo.2009.08.009.

Brant, R. (1990). Assessing Proportionality in the Proportional Odds Model for Ordinal Logistic Regression. Biometrics, 46(4), 1171-1178. https://doi.org/10.2307/2532457.

Breen, M., \& Gillanders, R. (2012). Corruption, Institutions and Regulation. Economics of Governance, 13(3), 263-285. https://doi.org/10.1007/s10101-012-0111-0.

Brunetti, A., \& Weder, B. (2003). A free press is bad news for corruption. Journal of Public Economics, 87(7-8), 1801-1824. https://doi.org/10.1016/S0047-2727(01)00186-4.

Brunetti, A., Kisunko, G., \& Weder, B. (1997). Credibility of Rules and Economic Growth: Evidence from a Worldwide Survey of the Private Sector. World Bank Economic Review, 12, 353-384. https://doi.org/10.1596/1813-9450-1760.

Budak, J., \& Rajh, E. (2011). Corruption as an Obstacle for doing Business in the Western Balkans: A Business Sector Perspective [EIZ Working Papers 1104]. Zagreb: The Institute of Economics.

CLDS. (2014). Corruption Assesment Report: Serbia. Belgrade: Center for Liberal Democratic Studies.

De Rosa, D., Gooroochurn, N., \& Gorg, H. (2010). Corruption and Productivity: Firmlevel Evidence from the BEEPS Survey [Policy Research working paper WPS 5348]. Washington, D.C.: World Bank.

Djankov, S., La Porta, R., Lopez-De-Silanes, F., \& Shleifer, A. (2002). The Regulation of Entry. Quarterly Journal of Economics, 117(1), 1-37. https://doi.org/10.1162/003355302753399436.

Dreher, A., \& Gassebner, M. (2013). Greasing the wheels of entrepreneurship? The impact of regulations and corruption on firm entry. Public Choice, 155(3), 413-432. https:// doi.org/10.1007/s11127-011-9871-2.

Dreher, A., Kotsogiannis, C., \& McCorriston, S. (2009). How do institutions affect corruption 
and the shadow economy? International Tax and Public Finance, 16(6), 773-796. https://doi. org/10.1007/s10797-008-9089-5.

Džafić, Z., Zahirović, S., Okičić, J., \& Kožarić, A. (2011). Internal and External Obstacles to the Develepment of SMEs in Bosnia and Herzegovina. Croatian Economic Survey, 13(1), 143-171.

EUROCHAMBRES. (2009). Obstacles to investing in the Western Balkans: The view of the private sector. Retrieved from http://www.eurochambres.eu/Content/Default. asp?PagelD=1\&DoclD=2071.

EBRD. (2015). Business Environment and Enterprise Performance Survey [Data file]. Retrieved from http://ebrd-beeps.com/data/.

EBRD. (2015a). The Business Environment in the Transition Region (BEEPS $\mathrm{V}$ Report). Retrieved from http://ebrd-beeps.com/reports/ beeps_v_report/.

Fritzen, S. A., Serritzlew, S., \& Svendsen, G. T. (2014). Corruption, Trust and their Public Sector Consequences: Introduction to the Special Edition. Journal of Comparative Policy Analysis: Research and Practice, 16(2), 117-120. https://doi.org/10.1080/13876988.201 4.896124.

Gamberoni, E., Gartner, C., Giordano, C., \& Lopez-Garcia, P. (2016). Is corruption efficiency-enhancing? A case study of nine Central and Eastern European countries [ECB Working Paper 1950]. Frankfurt am Main: European Central Bank.

Gauthier, B., \& Goyette, J. (2014). Taxation and corruption: Theory and firm-level evidence from Uganda. Applied Economics, 46(23), 2755-2765. http://dx.doi.org/10.1080/0003684 6.2014.909580.

Gatti, R. (1999). Corruption and Trade Tariffs, or a Case for Uniform Tariffs [Policy Research Working Paper 2216]. Washington, DC: The World Bank.

Graeff, P., \& Svendsen, G. T. (2013). Trust and corruption: The influence of positive and negative social capital on the economic development in the European Union. Quality \& Quantity, 47(5), 2829-2846. https://doi. org/10.1007/s11135-012-9693-4.

Guriev, S. (2004). Red Tape and Corruption. Journal of Development Economics, 73(2), 489-504. https://dx.doi.org/10.1016/j. jdeveco.2003.06.001.

Hall, R. E., \& Jones, C. I. (1999). Why Do Some Countries Produce So Much More
Output per Worker than Others? The Quarterly Journal of Economics, 114(1), 83-116.

Hanousek, J., \& Kochanova, A. (2016). Bribery environments and firm performance: Evidence from CEE countries. European Journal of Political Economy, 43, 14-28. https://doi.org/10.1016/j.ejpoleco.2016.02.002.

Harris, D. (2007). Bonding Social Capital and Corruption: A Cross-National Empirical Analysis [Environmental Economy and Policy Research Working Paper 27.2007]. Cambridge, UK: University of Cambridge, Department of Land Economics. Retrieved from https://ideas. repec.org/p/lnd/wpaper/200727.html.

Harris, G., \& Merve, A. (2012). The Scope for Measuring Public Opinion against Corruption: the Attitudes of Kwazulu-natal University Students. South African Journal of Economic and Management Sciences, 15(3), 282-293.

Hellman, J. S., Jones, G., Kaufmann, D., \& Schankerman, M. (2003). Measuring Governance, Corruption and State Capture: How Firms and Bureaucrats Shape the Business Environment in Transition Economies [Policy Research Working Paper 2312]. Washington DC: The World Bank. https://doi.org/10.1596/1813-9450-2312.

Hodgson, G., \& Jiang, S. (2007). The economics of corruption and the corruption of economics: An institutionalist perspective. Journal of Economic Issues, 91(4), 1043-1061. https://dx.doi.org/10.1080/00213624.2007.11507086.

Janković-Milić, V., Stanković, J., \& Marinković, S. (2014). The capacity of local governments to improve business environment: Evidence from Serbia. Proceedings of Rijeka Faculty of Economics, 32(2), 233-254.

Kaufmann, D. (2004). Corruption, Governance and Security: Challenges for the Rich Countries and the World [SSRN Scholarly Paper ID 605801]. Rochester, NY: Social Science Research Network. Retrieved from https://papers.ssrn.com/abstract $=605801$.

Kaufmann, D., \& Wei, S. J. (1999). Does "grease money" speed up the wheels of commerce? [Policy Research Working Paper]. Washington, DC: The World Bank. https://doi. org/10.1596/1813-9450-2254.

Kruskal, W. H., \& Wallis, W. A. (1952). Use of Ranks in One-Criterion Variance Analysis. Journal of the American Statistical Association, 47(260), 583-621. https://doi.org/10.1080/0162 1459.1952.10483441. 
Kruskal, W. H., \& Wallis, W. A. (1953). Errata: Use of Ranks in One-Criterion Variance Analysis. Journal of the American Statistical Association, 48(264), 907-911. https://doi. org/10.2307/2281082.

Lederman, D., Loayza, N. V., \& Soares, R. R. (2005). Accountability and Corruption: Political Institutions Matter. Economics \& Politics, 17(1), 1-35. https://doi.org/10.1111/ j.1468-0343.2005.00145.x.

Leff, N. (1964). Economic Development through Bureaucratic Corruption. American Behavioral Scientist, 82(2), 337-341. https:// doi.org/10.1177/000276426400800303.

Linhartová, V., \& Volejníková, J. (2015). Quantifying Corruption at a Subnational Level. E\&M Ekonomie a Management, 18(2), 25-39. https://doi.org/10.15240/tul/001/2015-2-003.

Lipset, S. M., \& Lenz, G. L. (2000). Corruption, culture, and markets. In L. E. Harrison, \& S. P. Huntington (Eds.), Culture matters. New York: Basic Books.

Long, J. S., \& Freese, J. (2006). Regression Models for Categorical Dependent Variables Using Stata (2nd ed.). Texas: Stata Press.

Mauro, P. (1995). Corruption and Growth. The Quarterly Journal of Economics, 110(3), 681-712. https://doi.org/10.2307/2946696.

Mauro, P. (1997). Why Worryabout Corruption? [IMF Economic Issues 6]. Washington, DC: IMF.

McKelvey, R. D., \& Zavoina, W. (1975). A statistical model for the analysis of ordinal level dependent variables. The Journal of Mathematical Sociology, 4(1), 103-120. https://doi.org/10.1080/0022250X.1975.9989847.

Melgar, N., Rossi, M., \& Smith, T. W. (2010). The Perception of Corruption. International Journal of Public Opinion Research, 22(1), 120131. https://doi.org/10.1093/ijpor/edp058.

Meon, P. G., \& Sekkat, K. (2005). Does corruption grease or sand the wheels of growth? Public Choice, 122(1), 69-97. https:// doi.org/10.1007/s11127-005-3988-0.

Nowak, R. (2001). Corruption and Transition Economies. Bucharest: Economic Analysis Division, United Nations Economic Commission for Europe.

O'Toole, C., \& Tarp, F. (2014). Corruption and inefficiency of capital investments in developing countries. Journal of International Development, 26(5), 567-597. https://doi. org/10.1002/jid.2997.

Paldam, M. (2002). The cross-country pattern of corruption: economics, culture and the seesaw dynamics. European Journal of Political Economy, 18(2), 215-240. https://doi.org/10.1016/S0176-2680(02)00078-2.

Persson, T., Tabellini, G., \& Trebbi, F. (2001). Electoral Rules and Corruption. Journal of the European Economic Association, 1(4), 958-989. https://doi.org/10.1162/154247603322493203.

Putnam, R. D., Leonardi, R., \& Nanetti, R. Y. (1994). Making Democracy Work: Civic Traditions in Modern Italy. Princeton, N.J.: Princeton University Press.

Rauch, J. E., \& Evans, P. B. (2000). Bureaucratic structure and bureaucratic performance in less developed countries. Journal of Public Economics, 75(1), 49-71. https://doi.org/10.1016/S0047-2727(99)00044-4.

Rose-Ackerman, S. (1999). Corruption and Government: Causes, Consequences, and Reform. New York: Cambridge University Press.

Rothstein, B., \& Uslaner, E. M. (2005). All for All: Equality, Corruption, and Social Trust. World Politics, 58(1), 41-72. https://doi. org/10.1353/wp.2006.0022.

Shleifer, A., \& Vishny, R. (1993). Corruption. The Quarterly Journal of Economics, 108(3), 599-617. https://doi.org/10.2307/2118402.

Smarzynska, B. K., \& Wei, S. J. (2000). Corruption and Composition of Foreign Direct Investment: Firm-Level Evidence [Policy Research Working Paper 2360]. Retrieved from https://ssrn.com/abstract=630732.

Stošić, I., Nikolić, D., \& Đukić, M. (2011). Attractiveness of Serbia for foreign direct investments: tendencies, obstacles and perspectives. In M. Radović-Marković, S. Redžepagić, J. S. Andrade, \& P. Teixeira (Eds.), Serbia and the European Union: economic lessons from the new member states (pp. 47-60). Coimbra: University of Coimbra, Faculty of Economics.

Tanzi, V. (1995). Corruption: Arm's-length Relationships and Markets. In G. Fiorentini, \& S. Pelzman (Eds.), The Economics of Organised Crime. Cambridge: Cambridge University Press.

Tanzi, V. (2013). Corruption and the Economy. Filozofija $i$ društvo, 24(1), 33-59. https://doi.org/10.2298/FID1301033T.

Treisman, D. (2000). The causes of corruption: a cross-national study. Journal of Public Economics, 76(3), 399-457. https://doi. org/10.1016/S0047-2727(99)00092-4.

Treisman, D. (2007). What Have We Learned About the Causes of Corruption 
from Ten Years of Cross-National Empirical Research? Annual Review of Political Science, 10(1), 211-244. https://doi.org/10.1146/annurev. polisci.10.081205.095418.

Van Duyne, P., \& Stocco, E. (2012). Corruption Policy in Serbia - from black box to transparent policy making. Oisterwijk: Wolf Legal Publishers.

Wolfe, R., \& Gould, W. (1998). An approximate likelihood-ratio test for ordinal response models. Stata Technical Bulletin, $7(42)$.

UNODC. (2013). Corruption and Crime in Serbia: The Impact of Bribery and Other Crime on Private Enterprise. Vienna: United Nations Office on Drugs and Crime.
World Economic Forum. (2016). Global Competitiveness Report. Geneva: World Economic Forum.

prof. dr Marija Džunić, Ph.D. University of Niš Faculty of Economics Serbia marija_dzunic@ni.ac.rs

prof. dr Nataša Golubović, Ph.D. University of Niš Faculty of Economics Serbia natasa.golubovic@eknfak.ni.ac.rs 


\title{
Abstract
}

\section{PERCEIVED CORRUPTION IN BUSINESS ENVIRONMENT: EXPLORING THE UNDERLYING CAUSES}

\author{
Marija Džunić, Nataša Golubović
}

This paper presents an empirical contribution to the literature that tends to explain variations in corruption perceptions. Drawing on theoretical assumptions about the impact of corruption on the quality of the business environment, we explore possible determinants of perceived corruption. We argue that explaining the determinants of corruption perceptions could be a valuable input for creating effective anti-corruption policies. In the paper, we perform a detailed analysis on the case of Serbia, a transition country with relatively widespread corruption in the business environment. Using the non-parametric analysis of variance test, we examine the significance of differences in the perceived spread of corruption across a number of independent variables (regions, size of locality, industry, size, and years of operation). Specifying an ordered logistic regression model, we estimate the relation between corruption perceptions and a number of potential causes: frequencies of unofficial payments or gifts for different purposes, the impact that unofficial payments to public officials have on the business operations of the respondents, as well as attitudes of the respondents about the quality of the judicial system and political stability. We find that perceptions of corruption as an obstacle to business operations can be linked to the frequency of unofficial payments to deal with customs and taxes, as well as the impact of unofficial payments to local or regional government officials on business performance of the respondents. The results provide useful insights into what policy measures are necessary to reduce the level of corruption, as well as how the effects of such measures can be assessed.

Key Words: Corruption, business environment, informal payments.

JEL Classification: D73, H11.

DOI: 10.15240/tul/001/2018-4-004 